\title{
Regulation of pancreatic PC1 and PC2 associated with increased glucagon-like peptide 1 in diabetic rats
}

\author{
Ying Nie, ${ }^{1}$ Masahiro Nakashima, ${ }^{1,2}$ Patricia L. Brubaker, ${ }^{3}$ Qiao-Ling Li, ${ }^{1}$ \\ Riccardo Perfetti, ${ }^{1}$ Erik Jansen, ${ }^{4}$ Yasmeen Zambre, ${ }^{5}$ Daniel Pipeleers, ${ }^{5}$ \\ and Theodore C. Friedman ${ }^{1}$ \\ ${ }^{1}$ Division of Endocrinology, Department of Medicine, Cedars-Sinai Research Institute-UCLA School of Medicine, \\ Los Angeles, California 90048, USA \\ ${ }^{2}$ Department of Molecular Pathology, Atomic Bomb Disease Institute, Nagasaki University School of Medicine, \\ Nagasaki 852-8253, Japan \\ ${ }^{3}$ Departments of Medicine and Physiology, University of Toronto, Toronto, Ontario, Canada M5S 1A8 \\ ${ }^{4}$ Laboratory for Molecular Oncology, Center for Human Genetics, University of Leuven and the Flanders Interuniversity \\ Institute for Biotechnology, Herestraat 49, B-3000 Leuven, Belgium \\ ${ }^{5}$ Diabetic Research Center, Vrije Universiteit Brussel, B-1090 Brussels, Belgium
}

Address correspondence to: Theodore C. Friedman, Drew University School of Medicine, Division of Endocrinology,

1621 E. 120th, Street Los Angeles, California 90059, USA. Phone: (323) 563-9353; Fax: (323) 563-9352;

E-mail: Friedmant@hotmail.com.

Ying Nie and Masahiro Nakashima contributed equally to this work.

Received for publication May 28, 1999, and accepted in revised form February 15, 2000.

\begin{abstract}
The pancreatic processing enzymes, PC1 and PC2, convert proinsulin to insulin and convert proglucagon to glucagon and glucagon-like peptide 1 (GLP-1). We examined the effect of streptozotocin (STZ) treatment on the regulation of these enzymes and the production of insulin, glucagon, and GLP-1 in the rat. Pancreatic PC1 and PC2 mRNA increased >2-fold and >4-fold, respectively, in rats receiving intraperitoneal STZ $(50 \mathrm{mg} / \mathrm{kg})$ daily for 5 days. Immunocytochemistry revealed that, although pancreatic islet cells in the STZ-treated rats were sparse and atrophic PC1, PC2, glucagon, and GLP-1 immunoreactivity increased dramatically in the remaining islet cells. Heightened PC1 and PC2 expression was seen in cells expressing glucagon but not in insulin-expressing cells. Furthermore, in STZ-treated rats, bioactive GLP-17-36 amide accumulated in pancreatic extracts and serum 3-and 2.5-fold, respectively, over control animals. This treatment also caused a 2 -fold increase in the ratio of amidated forms of GLP-1 immunoreactivity to total glucagon immunoreactivity in the pancreas but did not affect the ratio of proinsulin to insulin. We conclude that hyperglycemic rats have an increased expression of prohormone converting enzymes in islet $\alpha$ cells, leading to an increase in amidated GLP-1, which can then exert an insulinotropic effect on the remaining $\beta$ cells.
\end{abstract}

J. Clin. Invest. 105:955-965 (2000).

\section{Introduction}

Proglucagon is synthesized in the $\alpha$ cells of the pancreas and is processed to bioactive glucagon, glicentin-related polypeptide (GRPP), intervening peptide 1 (IP-1), and the major proglucagon fragment (MPGF), with the formation of only minimal amounts of glucagon-like peptide 1 (GLP-1) (1-3). The processing of proglucagon in the $\alpha$ cell of the pancreas differs from that of the $\mathrm{L}$ cell of the intestine due to different levels of the prohormone convertases, PC1 and PC2. In the $\alpha$ cell of the pancreas, the major hormonal product is glucagon with only trace amounts of GLP-1 formed, due to the exclusive presence of PC2 in that cell $(4,5)$. On the other hand, higher levels of PC1 (but not PC2) in the L cells of the intestine leads to GLP-1 biosynthesis (6). Glucagon acts to raise plasma glucose levels by stimulating hepatic glycogenesis and gluconeogenesis (7), whereas the bioactive form of GLP-1, GLP-17-36 amide, lowers plasma glucose levels by stimulating insulin release (8).
Insulin is exclusively synthesized in the $\beta$ cells of the pancreas as proinsulin. The processing of proinsulin to insulin is mediated by PC1 and PC2 (9-12). Some patients with type 2 diabetes have elevated serum levels of glucagon (13) and GLP-1 (14) and an increased ratio of proinsulin and proinsulin conversion intermediates to insulin in the circulation and in the pancreas (15-20). The physiological significance of these altered levels and the enzymes responsible for their generation in diabetes are unknown. Additionally, the regulation of the proglucagon and proinsulin converting enzymes, PC1 and PC2, in diabetic patients has not been examined.

Insights into the role of the prohormone convertases in the biosynthesis of insulin and glucagon have been elucidated from the study of mice lacking PC2 and in a patient with defective PC1. Mice with a knockout of PC 2 had a diminution of $\beta$ cells and elevated proinsulin and des-31,32-proinsulin levels with reduced (but still 
some) mature insulin $(21,22)$. Additionally, these mice also had hyperplasia of pancreatic $\alpha$ cells with impaired proglucagon processing without mature glucagon formation. GLP-1 levels were low. The authors postulated that the low circulating glucagon levels resulted in fasting hypoglycemia and a reduced rise in blood glucose after a glucose tolerance test (22). Recently, a patient with obesity and postprandial hypoglycemia with elevated glucose, proinsulin, and des-64,65-proinsulin levels, but no detectable insulin after an oral glucose tolerance test, was described (23). This patient was found to have mutations in both alleles of PC1, resulting in complete absence of active enzyme (24). These observations suggest that PC1 is required for proinsulin processing but that PC2 also contributes significantly to the processing. On the other hand, PC2 appears to be required for proglucagon processing to glucagon in the $\alpha$ cell.

We hypothesized that in an organism (rodent or normal patient) with normal glucose homeostasis, hyperglycemia would cause an upregulation in the pancreas of the enzymes capable of converting proinsulin to insulin. This would allow the organism to increase the amount of bioactive insulin in an attempt to reduce plasma glucose levels. We also wanted to examine whether PC1 and/or PC2 would be upregulated in the $\alpha$ cell in an attempt to increase the synthesis of glucagon and GLP-1, which are elevated in hyperglycemic states. To test these hypotheses, we made rats diabetic by treating them with daily low-dose intraperitoneal streptozotocin (STZ), which damages but does not entirely eliminate the islet $\beta$ cells of the pancreas (25). In rats, daily low-dose STZ produces hyperglycemia without the insulitis seen in mice (25). We elected to use an animal model of diabetes that is characterized by $\beta$-cell insufficiency rather than other models of diabetes in which insulin resistance is prominent, such as the $o b / o b$ mouse or the Zucker rat.

\section{Methods}

Animal treatments and RNA isolation. Male Wistar rats (200 g; 7-8 weeks) received a daily intraperitoneal injection of STZ (Sigma Chemical Co., St. Louis, Missouri, USA) (50 $\mathrm{mg} / \mathrm{kg}$ in $0.1 \mathrm{M}$ citrate buffer [pH 4.5]) for 5 days. Diabetes was observed clinically by weight loss, polydipsia, polyphagia, and polyuria in all rats. Control rats received daily injection of the vehicle. Animals were fasted overnight on the fifth day. In the morning of the sixth day, all rats were euthanized by $\mathrm{CO}_{2}$ narcosis and the tissues were immediately removed from animal and frozen in liquid nitrogen. Glucose concentration was determined using blood taken from the neck veins at the time of euthanasia and measured using an Accu-Chek Advantage glucose monitor (Boehringer-Mannheim, Indianapolis, Indiana, USA).

To prepare RNA from the pancreas, extreme care was used to prevent activation of RNases. The frozen tissue was homogenized in denaturing solution (4 M guanidinium thiocyanate, $25 \mathrm{mM}$ sodium citrate [pH 7]; 0.5 sarcosyl, 0.1 M 2-mercaptoethanol) according to the method of Chom- czynski and Sacchi (26). After phenol-chloroform extraction and isopropanol precipitation, the RNA was washed with $75 \%$ ethanol and dissolved in $0.5 \%$ SDS.

In vitro transcription of riboprobes. Rat PC1 and PC2 cDNA fragments subcloned into pBluescript II SK-vector (Stratagene, La Jolla, California, USA) were obtained from R. Mains (Johns Hopkins University, Baltimore, Maryland, USA). PC1 was linearized with Pst 1 and treated with Klenow (GIBCO BRL, Gaithersburg, Maryland, USA) to generate a 306-nucleotide (nt) fragment (243-548 of rat PC1). PC2 was linearized with Eag1 and treated with Klenow to generate a 361-nt fragment (353-713 of rat PC2). After linearization, the cDNA fragment was purified by phenol/chloroform extraction and ethanol precipitation. In vitro transcription was carried out according to the protocol described in Riboprobe in vitro transcription systems (Promega Corp., Madison, Wisconsin, USA) manual. Briefly, linearized cDNA $(1 \mu \mathrm{g})$ was transcribed with $20 \mathrm{U}$ of either T3 (PC1) or T7 (PC2) RNA polymerase and ${ }^{32} \mathrm{P}-$ UTP. All probes were gel purified on TBE mini-gels (Novex, San Diego, California, USA), stored at $-20^{\circ} \mathrm{C}$ and used within 3 days.

$R$ Nase protection assay. Pancreatic PC1 and PC2 mRNA levels were measured by ribonuclease protection assay (RPA) according to the protocol described in the RPAII Kit (Ambion Inc., Austin, Texas, USA) using $40 \mu \mathrm{g}$ of total RNA per protection assay. For each ${ }^{32} \mathrm{P}$-labeled probe, a control tube with yeast tRNA instead of tissue RNA and a probe-only tube were used. Samples were hybridized at $55^{\circ} \mathrm{C}$ for 16 hours and then treated with 1:100 RNase $\mathrm{A} / \mathrm{RN}$ ase $\mathrm{T} 1$ mixture for 30 minutes at $37^{\circ} \mathrm{C}$ and electrophoresed on a $6 \%$ denaturing polyacrylamide gel at $60 \mathrm{~W}$ for 2 hours. After electrophoresis, the gel was dried and exposed to $\mathrm{x}$-ray film at $-80^{\circ} \mathrm{C}$. The probe and protected sizes for PC1 were 360 and 305 $\mathrm{bp}$, respectively. The probe and protected sizes for PC2 were 375 and $360 \mathrm{bp}$, respectively. The probe was seen in protection assays without RNA and RNase, but absent when tissue mRNA and RNase were added. The protected bands of PC1, PC2, and $\beta$-actin were absent when yeast tRNA $(10 \mu \mathrm{g})$ was used instead of tissue RNA. The PC1 and PC2 mRNA levels were quantitated on an AlphaImager 2000 densitometry (Alpha Innotech Corp., San Leandro, California, USA) using $\beta$-actin as an internal control. The intensity of the signal was found to be linear with the amount of RNA. Four to 6 animals per treatment were studied.

Histology and immunohistochemistry. Formalin-fixed and paraffin-embedded tissues were used for histology and immunohistochemistry of PC1 and PC2. Paraffinembedded tissue was cut into 4- $\mu \mathrm{m}$ sections, deparaffinized in xylene, rehydrated in PBS, and stained with hematoxylin and eosin. For immunohistochemistry, deparaffinized sections were preincubated with $2 \%$ nonfat milk to prevent nonspecific binding and then incubated overnight at $4^{\circ} \mathrm{C}$ with anti-PC1- or anti-PC2-specific polyclonal antisera (both raised in rabbits against either a PC1-glutathione fusion protein or a PC2-glutathione fusion protein; ref. 27) at a 50-fold dilution. The 
slides were subsequently incubated with anti-rabbit IgG antibody conjugated with alkaline phosphatase (DAKO Corp., Carpinteria, California, USA) at a 500-fold dilution followed by visualization with 5-bromo-4-chloro-3indolyl phosphate and nitroblue tetrazolium chloride (BCIP/NBT) (DAKO Corp.). Control slides were performed by incubation with only the secondary antibody, without added primary antibody and did not show any staining. The slides were scanned using the Adobe Photoshop 4.0.1 program (Adobe Systems Inc., Mountain View, California, USA) and semiquantitation of staining levels for PC1 and PC2 of the scanned image was performed using the NIH Image program (version 1.61; National Institutes of Health, Bethesda, Maryland, USA). Four to 8 sections from 4 animals for each treatment were examined.

To clarify the distribution of PC1 and PC2 in pancreatic islets, double immunohistochemistry of PC1 and PC2 with insulin or glucagon was performed. The primary antibody for the first immunohistochemical reaction was PC1 or PC2 antiserum detected by alkalinephosphatase (as described above). After visualization of the first staining (some sections were photographed at this time), slices were washed with $0.1 \mathrm{~N}$ hydrochloridebuffered glycine $(\mathrm{pH} 2.2)$ to remove initial primary and secondary antibodies. Primary antibodies for insulin and glucagon were anti-human insulin $\mathrm{mAb}$ (Nichirei, Tokyo, Japan) at a concentration of $10 \mu \mathrm{g} / \mathrm{mL}$ and antihuman glucagon polyclonal antibody (DAKO Corp.) at a 75 -fold dilution. These antisera recognize rat insulin and glucagon and are expected to cross-react with proinsulin and proglucagon, respectively, although the amount of cross-reactivity with the prohormone was not provided by the manufacturers. The second immunohistochemical reactions for insulin and glucagon were visualized using peroxidase labeled-secondary antibody (DAKO Corp.) with diaminobenzidine (DAB) colorization. Positive cells were defined as percentage of each type of islet cell that stained positive for each PC. Control slides were performed in the double immunohistochemistry experiments by incubation with only the secondary antibody, without added primary antibody during the second immunohistochemical procedure, and did not show any staining in the second reaction.

We also stained pancreatic and intestinal sections with an antiserum for human GLP-17-37 (Phoenix Pharmaceuticals, Mountain View, California, USA) at a concentration of $1 / 500$. The second antibody was a biotinylated goat anti-rabbit immunoglobulin, and the signal was detected using the Vectastain ABC kit (Vector Laboratories, Burlingame, California, USA) with DAB as a substrate. The section was counterstained with methyl green. The GLP-1 antiserum cross-reacts with rat GLP$1_{1-37}$ and GLP-1 $1_{7-37}$, but not with GLP-1 $1_{1-36}$ amide, GLP17-36 amide, GLP-2, or glucagon; it is expected to cross-react to a certain degree with the proglucagon precursor and the MPGF intermediate, although the amount of crossreactivity was not provided by the manufacturer.
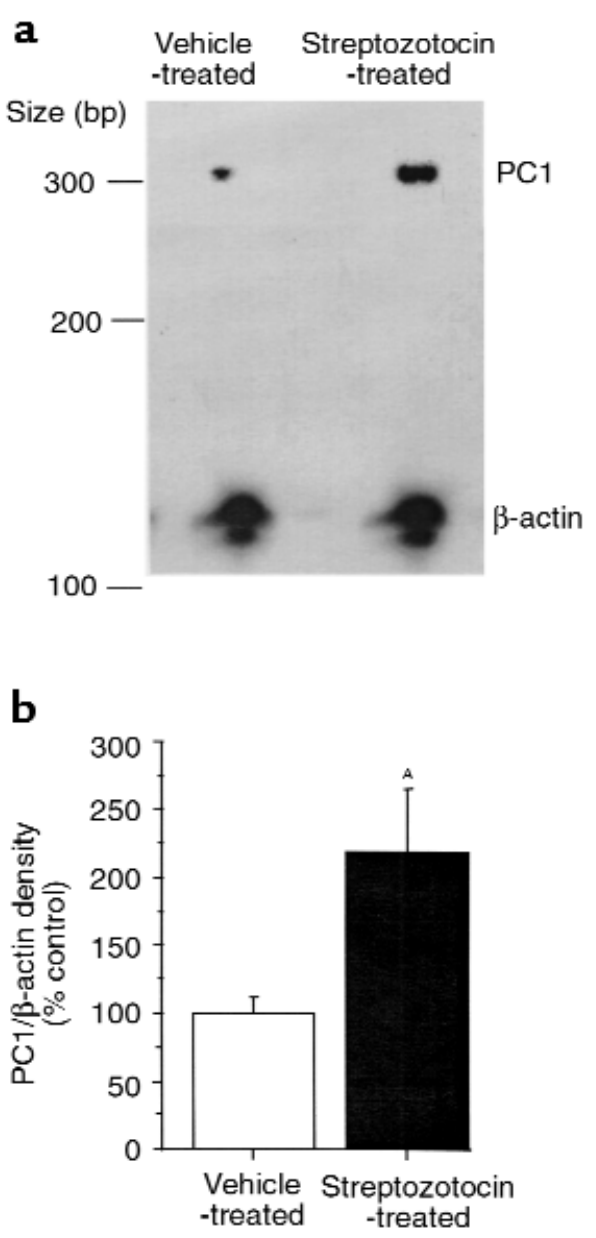

Figure 1

RPA of PC1 mRNA in the pancreas of STZ- and vehicle-treated rats. Antisense riboprobes ( ${ }^{32} \mathrm{P}$-labeled) for PC1 and $\beta$-actin were hybridized to $40 \mu \mathrm{g}$ total RNA from pancreata of animals treated with STZ ( $50 \mathrm{mg} / \mathrm{kg}$ intraperitoneally daily for 5 days) or vehicle and then digested with RNase as described in Methods. The probe sizes for PC1 and $\beta$-actin were 360 and $188 \mathrm{bp}$, respectively, which were seen in protection assays without RNA and RNase but were absent when tissue mRNA and RNase were added. The protected band sizes for PC1 and $\beta$-actin were 305 and 126 bp, respectively, and were absent when yeast tRNA $(10 \mu \mathrm{g})$ was used instead of tissue RNA. (a) Representative RPA. (b) Densitometric measurement of pancreatic PC1 mRNA levels normalized by $\beta$-actin from STZ-treated rats and expressed as percentage (mean \pm SEM) of vehicle-treated animals (4-6 animals per group). ${ }^{A} P<0.05$.

GLP-1-related peptides determined by RIA and reversedphase HPLC followed by RIA. Pancreata from control and STZ-treated rats were placed in $5 \mathrm{~mL}$ of extraction medium $(1 \mathrm{~N} \mathrm{HCl}$ containing 5\% formic acid, $1 \%$ trifluoroacetic acid [TFA], and $1 \% \mathrm{NaCl}$ ), minced in a Polytron (Brinkmann Instruments, Westbury, New York, USA), homogenized, and centrifuged. The supernatant was saved, and the pellet was reextracted in $5 \mathrm{~mL}$ of extraction buffer. The 2 supernatants were combined and passed twice through a C18 silica cartridge (Waters Corp., Milford, Massachusetts, USA). The peptides were eluted with $4 \mathrm{~mL} 80 \%$ isopropanol/0.1\% TFA and lyophilized. Similarly, blood was collected from the neck 

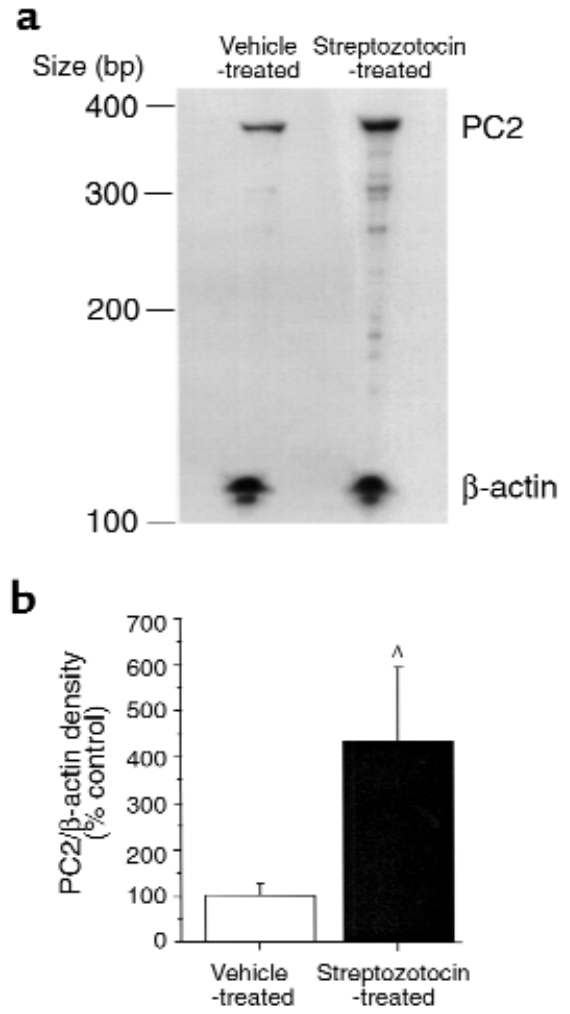

Figure 2

RPA of PC2 mRNA in the pancreas of STZ- and vehicle-treated rats. Forty micrograms total RNA from pancreata of animals treated with STZ (50 mg/ $\mathrm{kg}$ intraperitoneally daily for 5 days) or vehicle was hybridized with probes for PC2 and $\beta$-actin. The probe and protected sizes for PC2 were 375 and 360 bp, respectively. The probe was seen in protection assays without RNA and RNase but was absent when tissue mRNA and RNase was added. The protected band of PC2 was absent when yeast tRNA (10 $\mu \mathrm{g})$ was used instead of tissue RNA. (a) Representative RPA. (b) Densitometric measurement of pancreatic PC2 mRNA levels normalized by $\beta$-actin from STZ-treated rats and expressed as percentage (mean \pm SEM) of vehicle-treated animals (4-6 animals per group). ${ }^{A} P<0.05$.

veins of control and STZ-treated rats and placed in a tube containing a $10 \%$ solution of aprotinin (3.5 $\mathrm{TIU} / \mathrm{mL}) /$ EDTA $(32 \mathrm{mM}) /$ diprotin A $(0.1 \mathrm{mM})$. After centrifugation, the plasma was acidified by addition of 2 volumes 1\% TFA ( $\mathrm{pH}$ adjusted to 2.5 with diethylamine), passed twice through a C18 silica cartridge, eluted with $4 \mathrm{~mL} 80 \%$ isopropanol/0.1\% TFA, and lyophilized as already described here. The recovery of proglucagon-derived peptides using these method is greater than $88 \%(28,29)$.

To determine the identity of GLP- 1 immunoreactivity, pancreatic and plasma extracts were separated by reversed-phase HPLC (RP-HPLC) using a Waters Corp. Liquid Chromatography System and a C18 $\mu$ Bondapak column (Waters Corp.) as described previously $(1,30,31)$. Extracts were separated using a 30 -minute linear gradient of $45-68 \%$ solvent $B$ (solvent A: $0.1 \%$ phosphoric acid, $0.3 \%$ triethylamine, buffered with $\mathrm{NaOH}$ to $\mathrm{pH} 7.0$; solvent B: $60 \%$ acetonitrile, $40 \%$ solvent $\mathrm{A}$ ) at a flow rate of $1.0 \mathrm{~mL} / \mathrm{min}$. This gradient was followed by a 10 -minute isocratic run at $99 \%$ solvent B. HPLC fractions were lyophilized before RIA. COOH-terminally amidated forms of GLP-1 (GLP-1 1-36 amide and GLP-1 1-36 amide) were measured in pancreatic and plasma extracts and HPLC fractions using a GLP-17-36 amide antiserum (Affinity Research, Nottingham, United Kingdom) as reported previously $(1,30,31)$. Antiserum K4023, which recognizes the midsequence of glucagon, thus detecting all peptides containing glucagon, and antiserum 04A, which recognizes the free $\mathrm{COOH}$-terminal end of glucagon and is specific for glucagon, were also used on pancreatic extracts as described previously $(1,30,31)$.

Insulin and proinsulin determination by reversed-phase HPLC followed by RIA. Frozen rat pancreatic tissue were extracted in $2 \mathrm{M}$ acetic acid containing $0.25 \% \mathrm{BSA}$ using the modified method described previously (32). The tissue extracts were concentrated through Centricon concentrators (Amicon, Inc., Beverly, Massachusetts, USA) and then analyzed by RP-HPLC; this HPLC system separates insulin I and II as well as proinsulin I and II (33, 34). Collected fractions were analyzed for insulin immunoreactivity by an insulin RIA (35) using a polyclonal guinea pig anti-insulin antiserum raised at Vrije University. The following standards were injected to determine retention times: insulin I, 54 minutes; insulin II, 62 minutes; proinsulin I, 84 minutes; and proinsulin II, 91 minutes. Insulin immunoreactivity was summed for both insulin I and II and proinsulin I and II, and proinsulin/insulin ratios were calculated for both control and STZ-treated pancreata. The fractions eluting at the elution positions of proinsulin I and II showed insulin immunoreactivity; however, exact quantification of proinsulin content is not possible because of the unknown cross-reactivity of the anti-insulin antibody with proinsulin.

Statistical analyses. Statistical analysis for comparing 2 groups was performed using the Student's $t$ test. Owing to heteroscedasticity of variance, densitometric measurements from the RPA were subjected to logarithmic transformation before analysis.

\section{Results}

Characterization of STZ-treated rats. STZ-treated rats lost $32 \pm 11 \mathrm{~g}($ mean $\pm \mathrm{SD})$ in the 6 days while receiving STZ, whereas vehicle-treated rats gained $20 \pm 8 \mathrm{~g}$. At the time of sacrifice (day 6), STZ-treated rats had plasma glucose levels of $19.1 \pm 1.2 \mathrm{mmol} / \mathrm{L}$ (mean $\pm \mathrm{SEM}$; range $16.3-23.3 \mathrm{mmol} / \mathrm{L}$ ), whereas vehicle-treated rats had plasma glucose levels of $5.2 \pm 0.7 \mathrm{mmol} / \mathrm{L}$ (range 4.6-6.2 mmol/L; $P<0.0001$ ).

Effect of STZ on PC1 and PC2 mRNA levels in the pancreas. We hypothesized that under conditions of hyperglycemia, the rat would attempt to increase its PC1 and PC2 levels to convert more proinsulin to insulin. We used a quantitative RPA to measure PC1 and PC2 mRNA in rats that received STZ compared with control rats. STZ increased PC1 mRNA levels (corrected by $\beta$ actin) in the pancreas $2.2 \pm 0.06$-fold $(P<0.05)$ compared with rats that received vehicle (Figure 1). Pancre- 

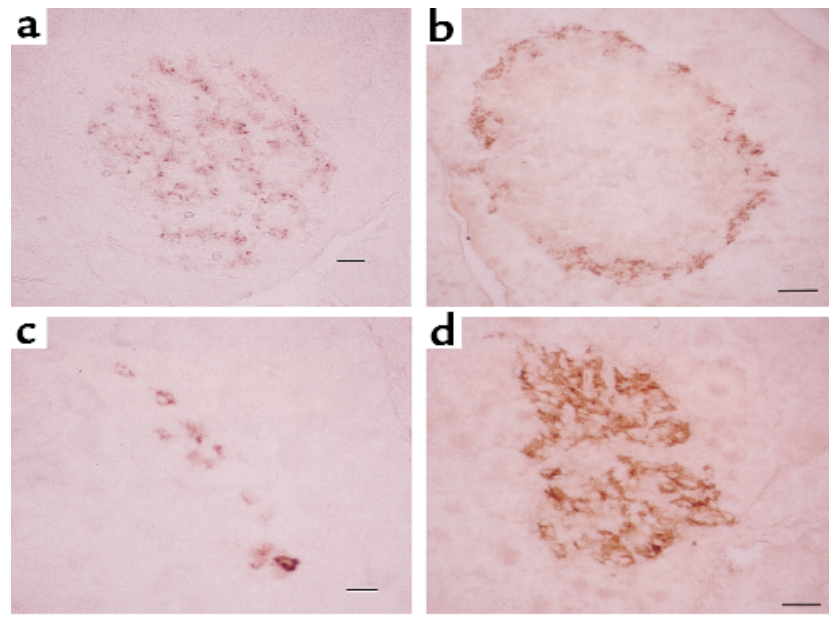

\section{Figure 3}

Immunohistochemistry (peroxidase method with DAB colorization) for insulin $(10 \mu \mathrm{g} / \mathrm{mL})(\mathbf{a}$ and $\mathbf{c})$ and glucagon (1/75 dilution) (b and $\mathbf{d})$ in pancreata from vehicle-treated ( $\mathbf{a}$ and $\mathbf{b}$ ) or STZ-treated ( $\mathbf{c}$ and $\mathbf{d})$ rats. In control pancreata, insulin immunoreactivity (a) is ubiquitously distributed in islets, whereas glucagon immunoreactivity $(\mathbf{b})$ is distributed in the marginal zone of the islets. In contrast, STZ-treated pancreata showed much more abundant and ubiquitous immunostaining for glucagon (d) than insulin (c). Scale bar $=20 \mu \mathrm{m} ; 4$ animals per group.

atic PC2 levels were also increased after STZ $4.35 \pm$ 0.07 -fold $(P<0.05)$ compared with rats that received vehicle (Figure 2).

Immunobistochemistry and immunocytochemistry of islet cell PC1 and PC2. We expected that a 5-day course of intraperitoneal STZ would damage the pancreatic islet cells. Thus, the fact that PC1 and PC2 mRNA were increased in the pancreata of STZ-treated rats was even more noteworthy, as the rats would likely have less islet cell mass. Hematoxylin and eosin staining demonstrated that STZ-treated islets were atrophic and sparse, whereas control islets appeared healthy and nonatrophic (data not shown).

We performed immunocytochemistry on pancreatic slices to study the intra-islet regulation of insulin and glucagon along with PC1 and PC2 in the STZ-treated rats. Using antiserum specific for insulin and glucagon, we found that in pancreas slices from control rats, insulin staining ( $\beta$ cells) (Figure 3a) was ubiquitously distributed throughout the islet, whereas glucagon staining ( $\alpha$ cells) (Figure $3 \mathrm{~b}$ ) was on the periphery of the islet. In the STZtreated pancreas, there was a dramatic increase in staining for glucagon (Figure 3d) but a decrease in staining for insulin (Figure 3c). Although there were many fewer insulin-staining cells in the STZ-treated pancreatic slices, those few remaining insulin-positive cells appeared to have more intense staining for insulin (Figure 3c) than did control-treated slices (Figure 3a). Using antiserum specific for PC1 and PC2, immunocytochemistry demonstrated that in control animals, PC1 immunoreactivity (Figure 4a) was distributed throughout the islets in a pattern similar to that of $\beta$ cells, whereas PC2 immunoreactivity (Figure 5a) was in lower abundance. In STZ-treated rats, on the other hand, the remaining islet cells had much higher levels of PC1 (Figure 4b) and PC2 (Figure $5 b)$ immunoreactivity compared with vehicle-treated rats (Figure 4a and Figure 5a, respectively). Semiquantitation of the mean staining intensity of PC1 and PC2 per islet showed that PC1 increased from $68.4 \pm 4.4$ (mean \pm SEM) pixels per islet in control pancreata to $125 \pm 1.8$ pixels per islet in the STZ-treated pancreata $(P<0.0005)$, whereas PC2 increased from $56.6 \pm 2.0$ pixels per islet in control pancreata to $90.0 \pm 9.6$ pixels per islet in the STZ-treated pancreata $(P<0.05)$.

We then performed double immunocytochemistry on islet cells to determine colocalization of PC1 and PC2 with insulin and glucagon. The percentage of insulinand glucagon-staining cells that are positive for PC1 and PC2 in both control and STZ-treated pancreata is shown in Table 1. In control islets, PC1 immunoreactivity was primarily colocalized with insulin-producing cells (85.4\%) (Figure 4c), but occasionally with glucagon-producing cells (9.2\%) (Figure 4d). On the other hand, in diabetic islets, PC1 expression was observed in both insulin-producing cells (71.7\%) (Figure $4 \mathrm{e}$ ) and glucagon-producing cells (95.4\%) (Figure $4 \mathrm{f})$. The percentage of PC1 in $\beta$ cells decreased in STZtreated islets compared with control islets $(P<0.05)$, whereas the percentage of $\alpha$ cells staining for PC1 substantially increased in STZ-treated islets compared with control islets $(P<0.005)$. Because the same islet section is stained for PC1 alone (Figure 4b) followed by PC1 and glucagon (Figure 4f), the costaining of PC1 and glucagon in $\alpha$ cells in STZ rats can be readily seen. In control islets, PC2 immunoreactivity was positive in both insulin-producing cells (81.3\%) (Figure 5c) and glucagon-producing cells (35.1\%) (Figure 5d). In diabetic islets, PC2 expression was observed in both insulin-producing cells (62.1\%) (Figure 5e) and glucagon-producing cells (88.4\%) (Figure 5f). The percentage positivity of PC2 went up dramatically in $\alpha$ cells $(P<0.0005)$, whereas it went down slightly in $\beta$ cells $(P$ $<0.05)$. Again, because the same islet section is stained for PC2 alone (Figure $5 b$ ) followed by PC2 and glucagon (Figure 5f), the costaining of PC2 and glucagon in $\alpha$ cells in STZ rats can be readily seen. Thus, in the STZtreated rats, both PC1 and PC2 increased in the $\alpha$ cells.

\section{Table 1}

PC1 and PC2 percentage positivity in pancreatic islet cells

$\begin{array}{llr}\text { Staining } & \text { Condition } & \text { Percent positive } \\ \text { PC1 in } \beta \text { cells } & \text { Control } & 85.4 \pm 2.9 \\ \text { PC1 in } \beta \text { cells } & \text { STZ-treated } & 71.7^{\mathrm{A}} \pm 1.7 \\ \text { PC2 in } \beta \text { cells } & \text { Control } & 81.3 \pm 2.1 \\ \text { PC2 in } \beta \text { cells } & \text { STZ-treated } & 62.1^{\mathrm{A}} \pm 2.8 \\ \text { PC1 in } \alpha \text { cells } & \text { Control } & 9.2^{2} \pm 1.2 \\ \text { PC1 in } \alpha \text { cells } & \text { STZ-treated } & 95.1^{\mathrm{B}} \pm 2.3 \\ \text { PC2 in } \alpha \text { cells } & \text { Control } & 35.1^{2} \pm 0.9 \\ \text { PC2 in } \alpha \text { cells } & \text { STZ-treated } & 88.4^{\mathrm{C}} \pm 1.1\end{array}$

$\beta$ cells are defined as cells staining for insulin; $\alpha$ cells are defined as cells staining for glucagon. Data are expressed as percentage of islet cell that stained positive for each $\mathrm{PC}$ and represent mean \pm SEM of 3 pancreata per condition. ${ }^{A} P<0.05 ;{ }^{B} P<0.005 ;{ }^{C} P<0.0005$. 

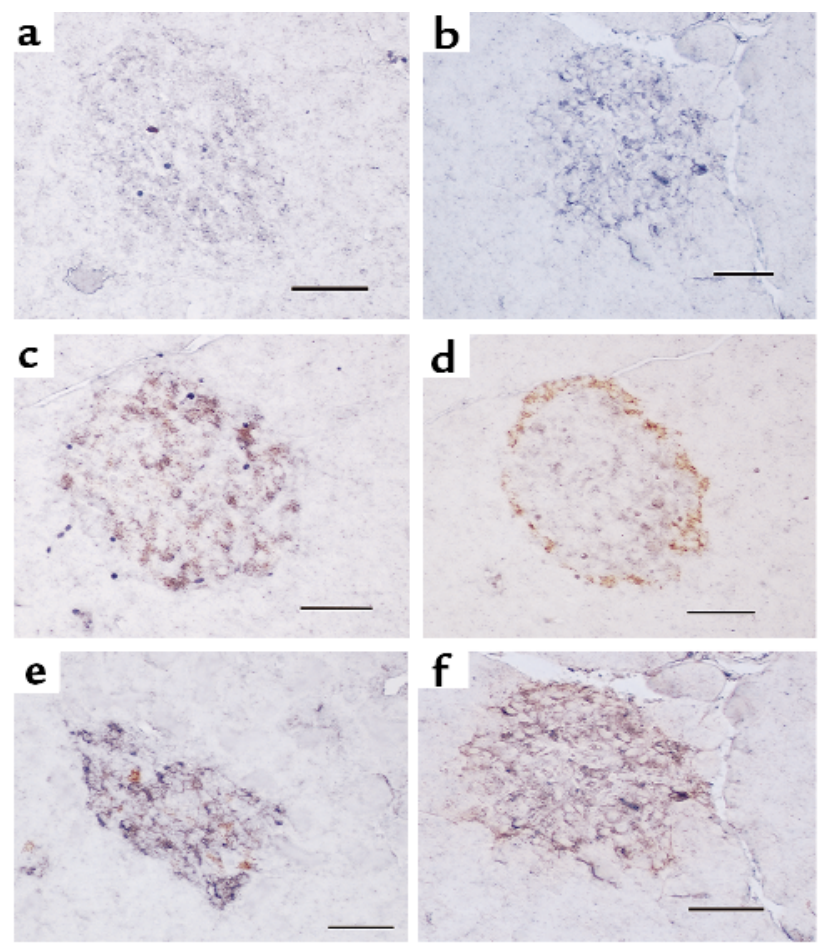

\section{Figure 4}

Immunohistochemistry (alkaline phosphatase method with NBT/BCIP colorization) for PC1 (1/50 dilution) in pancreata from vehicle-treated $(\mathbf{a})$ or STZ-treated $(\mathbf{b})$ rats and double immunohistochemistry staining for PC1 (1/50 dilution) (alkaline phosphatase method with NBT/BCIP colorization; purple) and insulin $(10 \mu \mathrm{g} / \mathrm{mL})$ (peroxidase method with DAB colorization; rust) (c and $\mathbf{e}$ ) or glucagon ( $1 / 75$ dilution) (peroxidase method with DAB colorization; rust) in pancreata from vehicle-treated (c and $\mathbf{d}$ ) or STZ-treated (e and $\mathbf{f}$ ) rats. PC1 was much more intense in diabetic islets (b) than in control islets (a) and was mainly colocalized with insulin-producing cells (c) but occasionally with glucagon-producing cells (d) in control islets. On the other hand, PC1 immunoreactivity was observed in both insulin-producing cells $(\mathbf{e})$ and glucagon-producing cells $(\mathbf{f})$ in diabetic islets. The increase in PC1 immunoreactivity appears confined to the glucagon-staining cells. Scale bar $=50 \mu \mathrm{m} ; 4$ animals per group.

Immunocytochemistry of islet cell GLP-1. Our finding of large amounts of immunoreactive PC1 in the $\alpha$ cells of STZ-treated rats (Figure 4f), coupled with the idea that PC1 is responsible for the biosynthesis of bioactive GLP-1, led us to perform immunocytochemistry for GLP-1 in islets of STZ- and vehicle-treated islets. We used a GLP-17-37 antiserum recommended for immunocytochemistry that detects GLP- $1_{7-37}$ and GLP- $1_{1-37}$ and may also detect the proglucagon precursor and the MPGF intermediate. As shown in Figure 6a, GLP-1 immunoreactivity was faint in control islets and localized along the periphery of the islets ( $\alpha$ cells). On the other hand, GLP-1 immunoreactivity was strong and localized throughout the islets (likely in $\alpha$ cells) in STZ-treated animals (Figure 6b). This antiserum also showed localized positive staining in $\mathrm{L}$ cells of the small and large intestine (data not shown).

GLP-1-related peptide levels in the pancreata and plasma of control and STZ-treated rats. The finding of increased GLP-
1 and PC1 immunoreactivity in the pancreata of STZtreated rats led us to postulate that bioactive GLP-17-36 amide would be formed. To quantitate the amidated forms of GLP-1 (GLP- $1_{1-36}$ amide and GLP-17-36 amide), we measured pancreatic and plasma extracts by RIA using an antiserum specific for the $\mathrm{COOH}$-terminally amidated forms of GLP-1. As shown in Figure 7, pancreatic content (Figure 7a) of the amidated forms of GLP-1 was increased 3-fold in the STZ-treated rat $(P<0.005)$, and the ratio of amidated GLP-1 to total glucagon immunoreactivity increased 2 -fold $(P<0.01)$. In contrast, the ratio of glucagon to total glucagon immunoreactivity was similar in the control $(0.65 \pm 0.02)$ compared with the STZ-treated $(0.58 \pm 0.05)$ pancreatic extract $(P=\mathrm{NS})$. It is noteworthy that the majority of proglucagon is processed to glucagon (58-65\%), while even in the STZtreated pancreata, amidated forms of GLP-1 represent less than $1 \%$ of total glucagon immunoreactivity.

We also found that plasma content (Figure $7 \mathrm{~b}$ ) of the amidated forms of GLP-1 was increased 2.5-fold ( $P$ < $0.05)$ in the STZ-treated rats compared with the vehicletreated rats.

To identify which amidated forms of GLP-1 are produced in the pancreata and plasma of STZ-treated and control rats, we subjected the pancreatic pancreata and plasma extracts to HPLC/RIA analysis using an antiserum specific for the amidated forms of GLP-1. As shown in a representative HPLC profile (Figure 7c) using pancreatic extracts, the majority of amidated GLP-1 immunoreactivity coeluted with GLP-17-36 amide (fractions 20-21) in the pancreata of the STZ-treated and control rats. The smaller peak at position 23 may represent GLP$1_{9-36}$ amide, which is generated from GLP-17-36 amide by the action of dipeptidyl-peptidase IV $(36,37)$. Similarly, the majority of amidated GLP-1 in the plasma of STZ-treated and control rats coeluted with GLP-1 7-36 amide $_{\text {(Figure }}$ 7d). Higher levels of amidated GLP-1 immunoreactivity were found in the HPLC/RIA determinations of both the pancreatic and plasma extracts of the STZ-treated compared with the control rat.

Pancreatic proinsulin and insulin levels in the pancreata of control and STZ-treated rats. We initially hypothesized that hyperglycemia caused by STZ injection would provide a signal to the $\beta$ cell to increase the proinsulin processing enzymes, PC1 and PC2. This hypothesis was confirmed in our RPAs that showed an upregulation of PC1 and PC2 mRNA levels in whole pancreata from STZ-treated rats (Figures 1 and 2). However, double immunocytochemistry showed that the increase in PC1 and PC2 was in the $\alpha$ cells without a major effect in the $\beta$ cell. To determine whether there was a change in PC1 and PC2 activity in the $\beta$ cell capable of altering the ratio of proinsulin to insulin, we separated pancreatic extracts of STZ- and vehicle-treated rats by HPLC and analyzed each fraction for insulin immunoreactivity using an antiserum that recognizes both proinsulin I and II and insulin I and II. Pancreatic proinsulin and insulin content and proinsulin to insulin ratio in control and STZtreated pancreata are shown in Table 2. Pancreatic 

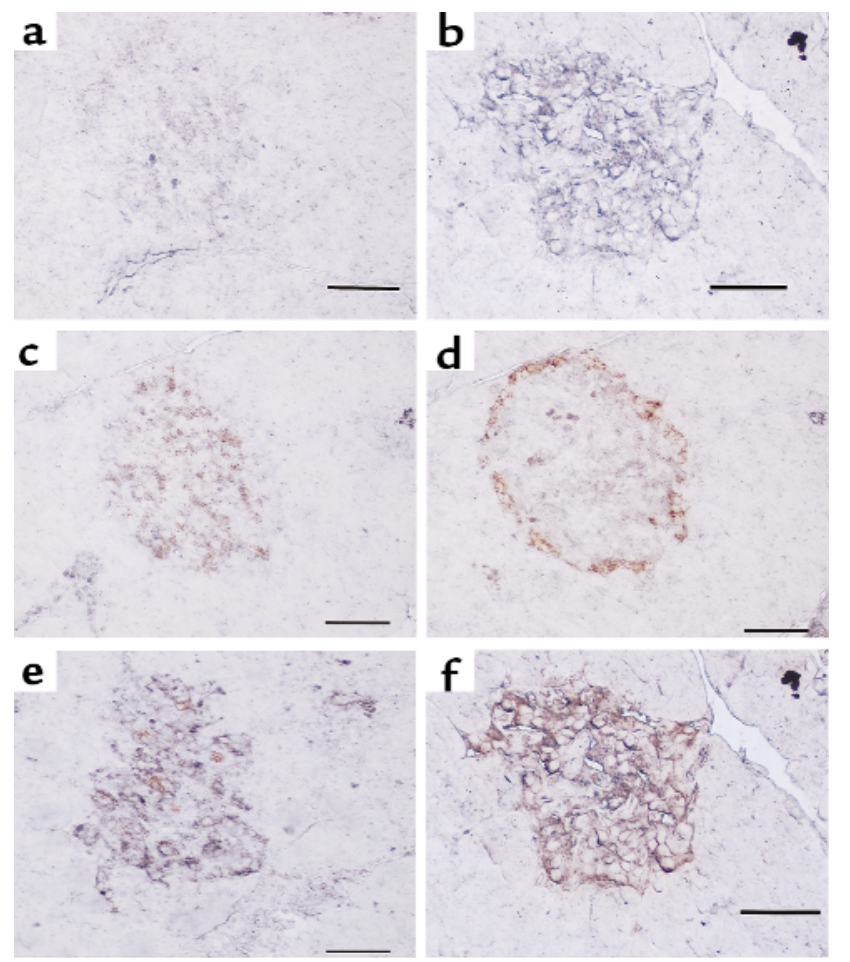

\section{Figure 5}

Immunohistochemistry (alkaline phosphatase method with NBT/BCIP colorization) for PC2 (1/50 dilution) in pancreata from vehicle-treated (a) or STZ-treated (b) rats and double immunohistochemistry staining for PC2 (1/50 dilution) (alkaline phosphatase method with NBT/BCIP colorization; purple) and insulin $(10 \mu \mathrm{g} / \mathrm{mL})$ (peroxidase method with $\mathrm{DAB}$ colorization; rust) (c and $\mathbf{e}$ ) or glucagon ( $1 / 75$ dilution) (peroxidase method with DAB colorization; rust) in pancreata from vehicle-treated (c and $\mathbf{d}$ ) or STZ-treated (e and $\mathbf{f}$ ) rats. PC2 was much more intense in diabetic islets (b) than in control islets (a). PC2 immunoreactivity was mainly colocalized with insulin-producing cells (c) but also with glucagon-producing cells (d) in control islets, whereas PC2 immunoreactivity was strong in both insulin-producing cells (e) and glucagon-producing cells (f) in diabetic islets. The increase in PC2 immunoreactivity occurred in the glucagon-staining cells. Scale bar $=50 \mu \mathrm{m} ; 4$ animals per group.

insulin levels (both insulin I and II) were higher in control rats than in STZ-treated rats (Table 2), with low levels of proinsulin in both groups. The ratio of proinsulin to insulin was similar in both control and STZ-treated pancreata. This demonstrates that proinsulin to insulin conversion is not effected by STZ treatment and concurs with our immunocytochemical findings that the increase in PC1/PC2 with STZ is limited to the $\alpha$ cells.

\section{Discussion}

The present results demonstrate that a 5-day treatment with STZ increased PC1 and PC2 mRNA levels in the pancreas (Figures 1 and 2). This increase in mRNA levels may be due to either increased transcription or increased stability of the mRNA and leads to increased PC1 and PC2 protein levels in the remaining islet cells as demonstrated by immunocytochemistry (Figures 4 and 5). Most unexpectedly, the increase in both PC1 and
PC2 protein was confined to the $\alpha$ cells, without an increase in the $\beta$ cells. Thus, in the diabetic pancreas there is abundant expression of both PC1 and PC2 in the $\alpha$ cells (Figures $4 \mathrm{f}$ and $5 \mathrm{f}$ ), whereas in euglycemia, $\alpha$ cells contain PC2 (Figure 5d) with only low levels of PC1 (Figure $4 \mathrm{~d}$ ). This finding of low PC1 in normal $\alpha$ cells replicates that of other groups $(38,39)$, who found either no PC1 or trace amounts of PC1 in rat $\alpha$ cells, respectively. The increased PC1 and PC2 in the $\alpha$ cells is likely to have profound effects on proglucagon processing. We found increased glucagon immunoreactivity in STZ-treated $\alpha$ cells (Figure 3); however, the ratio of glucagon to total glucagon immunoreactivity was unchanged, indicating that the increase in glucagon immunoreactivity likely represents increase in the levels of proglucagon mRNA and that the increase in PC2 likely represents an attempt of the $\alpha$ cell to have a coordinated increase in substrate and processing enzyme. This is similar to the coordinated increase in pituitary pro-opiomelanocortin (POMC) and PC1 seen with cytokine treatment (40) and that in POMC, PC2, and carboxypeptidase $\mathrm{H}$ seen with dopamine treatment (41). Another, more novel ramification is that because PC1 has been shown to generate the insulinotropic hormone, GLP-1 $1_{7-37}$, from proglucagon in intestinal $\mathrm{L}$ cells $(1,42,43)$, the induction of PC 1 in the diabetic $\alpha$ cell would generate more GLP-1 $1_{7-37}$ (and its amidated derivative, GLP-17-36 amide), which may act in a paracrine manner on neighboring $\beta$ cells to stimulate insulin and ultimately to reduce glucose levels. This is confirmed by both our GLP-1 immunoreactivity studies (Figure 6) and our HPLC/RIA studies (Figure 7). GLP-1 immunoreactivity was found in low abundance in the periphery of the control islets (Figure 6a), a finding that agrees with that of previous studies, in which small amounts of GLP-17-37 and GLP-17-36 amide were found in mouse pancreatic extracts (44) and small amounts of GLP-1 immunoreactivity were found in rat islets (45). In contrast, we found a large increase in GLP-1 immunoreactivity in diabetic islets (Figure 6b) accompanied by an increase in bioactive GLP-17-36 amide in both the pancreas and the serum of diabetic rats (Figure 7). The increased
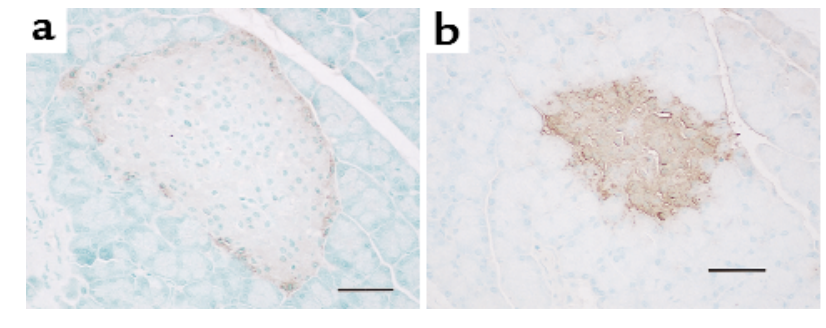

Figure 6

Immunohistochemistry (peroxidase method with DAB colorization) for GLP-1 (1/500 dilution) in pancreata from vehicle-treated (a) or STZ-treated (c and d) rats. This antiserum recognizes GLP-1 7-37 $_{7-3}$ and GLP-1 1-37) and may recognize proglucagon and MPGF, but not amidated forms of GLP-1 or glucagon. A large increase in GLP-1 immunoreactivity is seen in the STZ-treated islets corresponding to cells that stain for glucagon. Scale bar $=50 \mu \mathrm{m} ; 2$ animals per group. 
ratio of amidated GLP-1 to total glucagon immunoreactivity also indicates that the increase in amidated forms of GLP-1 is not merely due to an increase in proglucagon, but represents an alteration in processing of the proglucagon precursor. The increased levels GLP17-36 amide will likely have insulinotropic effects on the remaining islets (46-48). Thus, whether the induction of PC1 and PC2 in the $\alpha$ cell alleviates or exacerbates diabetes would depend on the ratio of glucagon (expected to raise plasma glucose) to GLP-1 1 -36 amide (expected to lower plasma glucose) produced by the $\alpha$ cell, which would be influenced by many factors including the levels of PC1 and PC2 in the secretory granule of the $\alpha$ cells. The proposed processing of proglucagon to GLP1 and glucagon is summarized in Figure 8.

It is well known that hyperglucagonemia and $\alpha$-cell hypertrophy occur both in animal models of diabetes (49, 50) and in patients with diabetes (13) in spite of the hyperglycemia that on first glance would be expected to reduce glucagon levels. This increase in glucagon production is probably caused by low insulin levels in diabetes $(7,49)$, and there is evidence that the glucagon gene is negatively regulated by insulin (51). Another intriguing explanation is that the increase in glucagon in diabetes

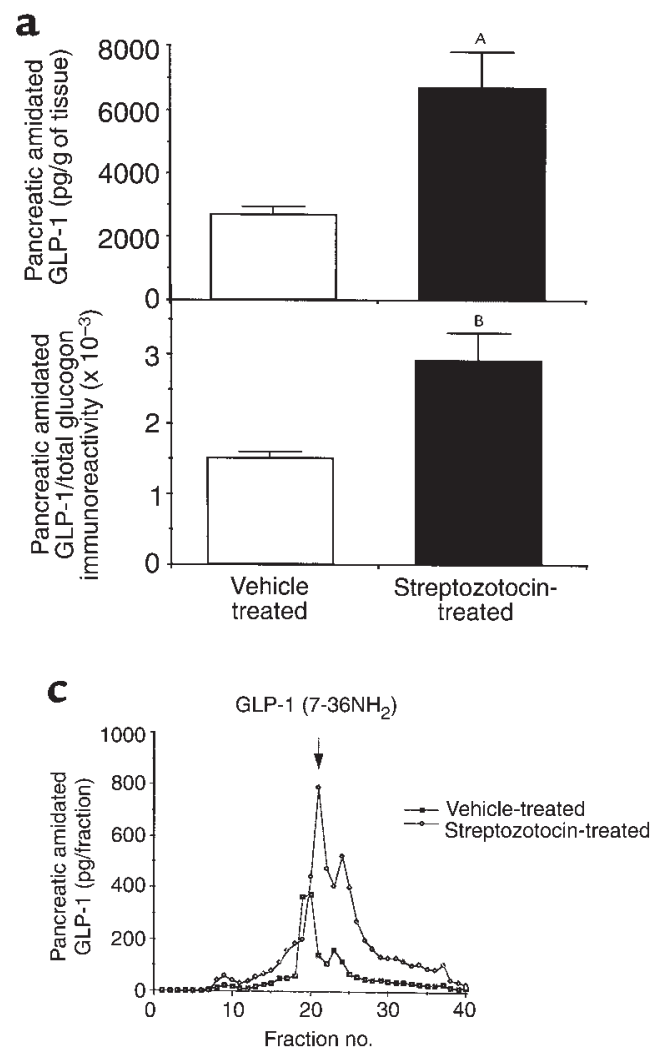

occurs as a side product of the increase in proglucagon mRNA, with the primary purpose of this increase being to increase insulinotropic GLP-1 production. It was previously thought that the source of the increased GLP-1 seen in diabetes was the L cells of the intestine (14), although our results demonstrate that the formation of GLP- $1_{7-36 \text { amide }}$ is increased in the $\alpha$ cells of the STZ-treated rat. The increase in amidated GLP-1 immunoreactivity in the plasma of the STZ-treated rats (Figure 7d) may be derived from either the $\alpha$ cells or the L cells, although the contribution by the former is likely to be small.

In contrast to the increase in glucagon-staining cells, PC1 and PC2 did not increase in the insulin-staining cells in pancreata from STZ-treated rats, and, in fact, the percentage of insulin staining cells positive for PC1 and PC2 decreased in the STZ-treated rat (Table 2). This was accompanied by HPLC/RIA studies that demonstrated that the ratio of proinsulin to insulin did not change in STZ-treated pancreata. Our data do not support the hypothesis that $\beta$-cell PC1 and/or PC2 would be upregulated in an attempt to increase proinsulin processing to maintain glucose homeostasis. We interpret the discrepancy between these results and our hypothesis by suggesting 1 of 2 possibilities. One is that
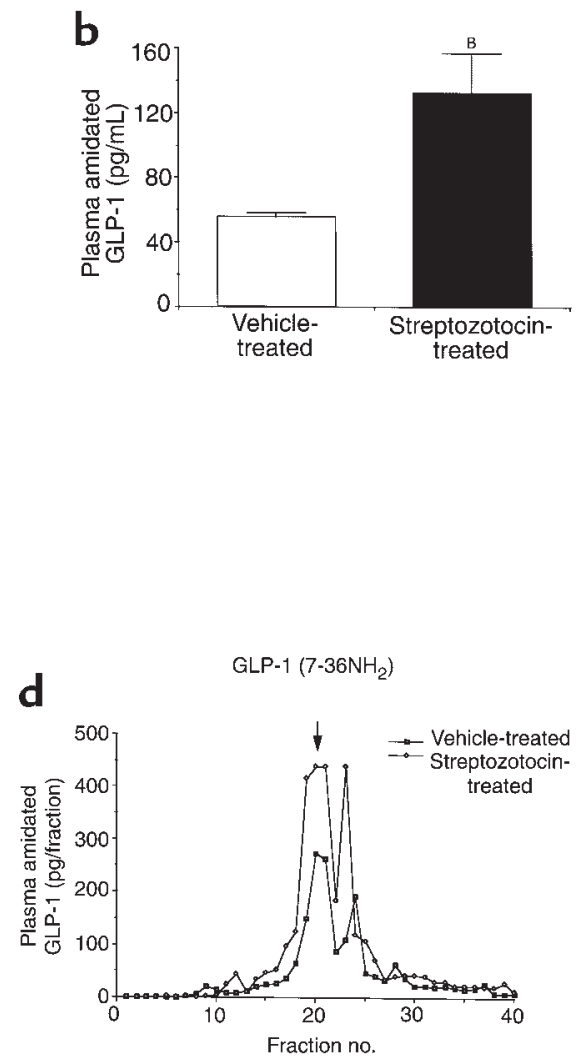

\section{Figure 7}

(a) Total content of amidated forms of GLP-1 in pancreatic extracts and ratio of amidated GLP-1 (using an antiserum that recognizes the amidated forms of GLP-1 [GLP-1 1 -36 amide and GLP-1 $7-36$ amide]) to total glucagon immunoreactivity (using an antiserum that recognizes all glucagoncontaining peptides). Six animals per group. (b) Total content of amidated forms of GLP-1 in plasma extracts. Three to 4 animals per group. Representative RP-HPLC/RIA profiles of amidated forms of GLP-1 immunoreactivity in pancreatic extracts (c) and plasma extracts (d) from control and STZ-treated rats. GLP-1 1-36 amide had a retention time of 19 minutes, and GLP-1 7-36 amide had a retention of 21 minutes. Two $\mathrm{HPLC} / \mathrm{RIA}$ profiles (that were similar) were obtained for each treatment for both plasma and pancreatic extracts. ${ }^{A} P<0.005,{ }^{B} P<0.01$. 


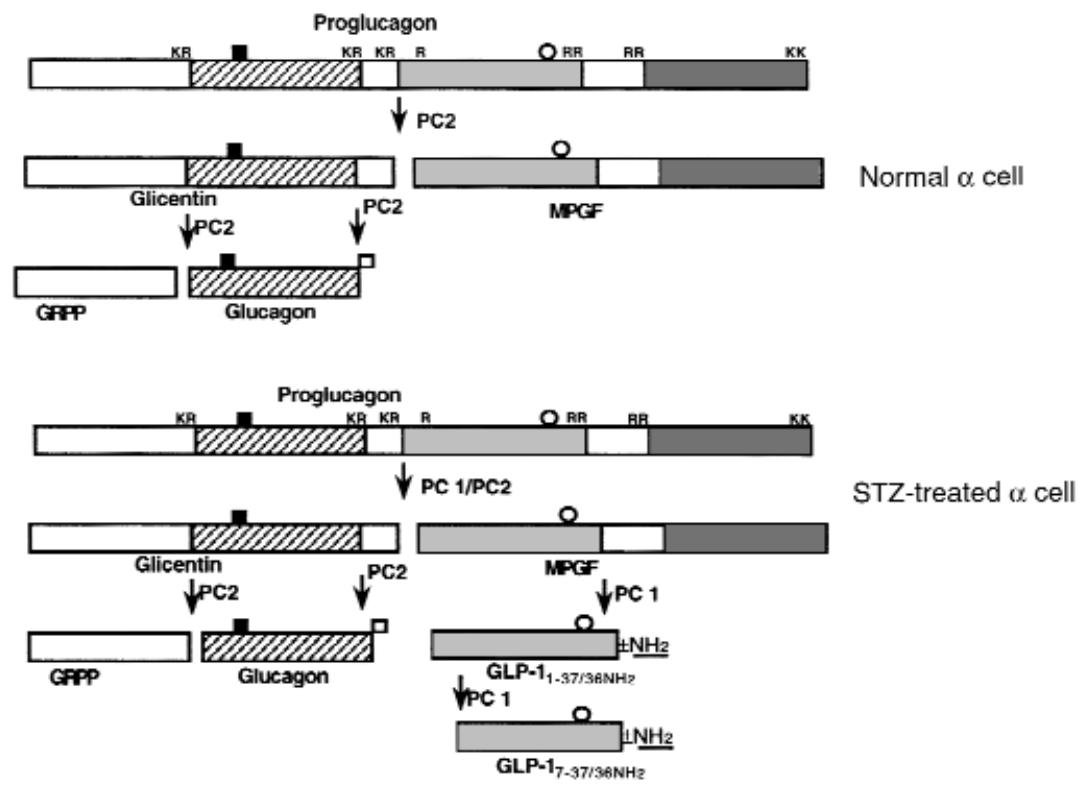

Figure 8

Diagram of postulated processing of proglucagon to glucagon- and GLP-1-related peptides in normal and STZ-treated $\alpha$ cells. Antibodies used in this study: Filled squares, K4023; open squares, 04A; open circles, GLP-1 (used for immunocytochemistry); (dark gray bars) GLP-1 amide. A small amount of GLP-1 $1_{7-36}$ amide is generated in normal $\alpha$ cells, whereas a large amount of proglucagon or MPGF is present in both control and STZ-treated $\alpha$ cells.

STZ, by damaging the $\beta$ cells, does not allow the normal upregulation of PC1/PC2, which would occur in healthy $\beta$ cells. The other possibility is that different intracellular transcription factors are present in the $\alpha$ cell compared with the $\beta$ cell, which allow the insulin/glucose regulation of PC1 and PC2 in the former cell. Different models of hyperglycemia would be helpful in elucidating the glucose and insulin regulation of these processing enzymes.

The islet cell (especially the $\alpha$ cell) changes in PC1 and PC2 content could be due to hyperglycemia, hypoinsulinemia, or the STZ administration. STZ treatment is reported to be specific for $\beta$ cells, as they contain the high-affinity Glut- 2 transporter, whereas $\alpha$ cells, which lack this transporter, are spared (52). In fact, the loss of ordered morphology of the STZ-treated islet ( $\alpha$ cells throughout the islet, instead of on the periphery) is likely due to selective damage of the $\beta$ cells. Thus, we do not suspect that the STZ itself is causing the increase in PC1 and PC2 in the $\alpha$ cells. In $\beta$ cells, insulin decreases intracellular cAMP (53) and glucose increases cAMP $(54,55)$, whereas in $\alpha$ cells, the insulin and glucose regulation of cAMP has not been studied. Both the low insulin and high glucose in the STZ-treated islet would be expected to increase PC1 and PC2 promoter activity, as the promoter of these 2 genes has cAMP-response elements (CREs) (56-59). In other experiments, we found that glucose stimulates PC1 and PC2 promoter activity in the insulin-secreting RIN 1046-38 cell line and the glucagon-secreting $\alpha$ TC1- 6 cell line, and that for PC1, this stimulation required intact CREs on the PC1 promoter (Q.-L. Li et al., in preparation). Thus, we postulate that the regulation of glucose in vivo seen in this current study is at the level of transcription and involves a cAMP-mediated pathway.

Other laboratories have studied the glucose regulation of the PCs. In very short-term (less than 1 hour) experiments studying the regulation of glucose on the PCs in normal rat islets, glucose stimulated the biosynthesis of PC1 but not PC2 (60). This regulation was at the level of translation. In islets from $o b / o b$ (leptin-deficient) mice that contain a higher ratio of $\beta$ cells to $\alpha$ cells, glucose stimulated PC2 and PC1 7.5- to 10-fold (61). A more recent study examined the longer-term (6-48 hours) regulation of PC1 and PC2 by glucose in insulin-producing $\beta$ TC 3 cells (62). Glucose stimulated PC1, PC2, and proinsulin mRNA levels by increasing gene transcription. Similarly, the insulin-producing MIN6 cell line also had an increase in proinsulin, PC1, and PC2 biosynthesis when exposed to high glucose levels (63). In contrast, in rats made hyperglycemic by a 48hour infusion of $50 \%$ glucose, there was an increase in PC1 mRNA and PC1 biosynthesis, but a decrease in immunoreactive PC1 and PC2 levels (64). Our experimental paradigm of daily STZ injection for 5 days led to

\section{Table 2}

Pancreatic insulin and proinsulin content

\begin{tabular}{lccc}
\hline Condition & Insulin & Proinsulin & Proinsulin/Insulin \\
& $\mu \mathrm{g} / \mathrm{g}$ tissue & $\mu \mathrm{g} / \mathrm{g}$ tissue & $\mu \mathrm{g} / \mu \mathrm{g}$ \\
Control & $107 \pm 15$ & $3.16 \pm 0.41$ & $0.030 \pm 0.002$ \\
STZ-treated & $6^{\mathrm{A}} \pm 1$ & $0.20^{\mathrm{A}} \pm 0.03$ & $0.034 \pm 0.003$ \\
\hline
\end{tabular}

Data represent mean \pm SEM of 4 pancreata per condition. ${ }^{A} P<0.05$. 
an animal that is hyperglycemic and insulinopenic and is different from the other experimental paradigms already described here. We chose to examine an acute model of $\beta$-cell insufficiency resulting in hyperglycemia as induced by low-dose STZ treatment (25).

In conclusion, this study demonstrates that the STZ treatment results in the upregulation of PC1 and PC2 in the $\alpha$ cells. This may result in an increase in glucagon production that would exacerbate hyperglycemia. However, we also found an increase in serum and pancreatic bioactive GLP-1 $1_{7-36}$ amide that would help alleviate hyperglycemia, if sufficient $\beta$ cells are present. These results demonstrate that regulation of PC1 and PC2 may have an important role in glucose homeostasis and that abnormal regulation of these enzymes may play a role in both type 1 and type 2 diabetes. Further studies are needed to explore the role of these enzymes in patients with diabetes and in animal models of diabetes.

\section{Acknowledgments}

This research was supported by a Training Grant in Endocrinology and Diabetes (DK-287235 to Y. Nie); Geconcentreerde Onderzoekacties 1997-2001 (E. Jansen); an American Diabetes Association Research grant and a National Institute of Health grant (DA00276) (T.C. Friedman); the Medical Research Council of Canada and the Canadian Diabetes Association (P.L. Brubaker); and grants from Belgian Fonds voor Wetenschappelijk Onderzoek (3.0057.94), the services of the Prime Minister (Interuniversity Attraction Pole P4/21), and the Juvenile Diabetes Foundation (JDF-DIRP 9597) (D. Pipeleers). T.C. Friedman is a Charles. E. Culpeper Fellow. The authors thank R. Mains for supplying the rat PC1 and PC2 cDNA and N. Birch (University of Auckland, New Zealand) for supplying the PC1 and PC2 antiserum. We thank S. Melmed (CedarsSinai Medical Center), G. Grodsky (University of California-San Francisco), and D. Cool (Wright State University) for helpful comments concerning the manuscript, and D. Steiner (University of Chicago) and C. Rhodes (University of Texas-Southwestern) for helpful discussions on this project.

1. Dhanvantari, S., Seidah, N.G., and Brubaker, P.L. 1996. Role of prohormone convertases in the tissue-specific processing of proglucagon. Mol. Endocrinol. 10:342-355.

2. Rouille, Y., et al. 1995. Proteolytic processing mechanisms in the biosynthesis of neuroendocrine peptides: the subtilisin-like proprotein convertases. Front Neuroendocrinol. 16:322-361.

3. Rothenberg, M.E., et al. 1995. Processing of mouse proglucagon by recombinant prohormone convertase 1 and immunopurified prohormone convertase 2 in vitro. J. Biol. Chem. 270:10136-10146.

4. Steiner, D.F. 1998. The proprotein convertases. Curr. Opin. Chem. Biol. 2:31-39.

5. Steiner, D.F., et al. 1996. The role of prohormone convertases in insulin biosynthesis: evidence for inherited defects in their action in man and experimental animals. Diabetes Metab. 22:94-104.

6. Scopsi, L., Gullo, M., Rilke, F., Martin, S., and Steiner, D.F. 1995. Proprotein convertases (PC1/PC3 and PC2) in normal and neoplastic human tissues: their use as markers of neuroendocrine differentiation. J. Clin. Endocrinol. Metab. 80:294-301.

7. Unger, R., and Orci, L. 1995. Glucagon secretion, alpha cell metabolism, and glucagon action. In Endocrinology. L. DeGroot, editor. W.B. Saunders. Philadelphia, PA. 1337-1353.
8. Orskov, C. 1992. Glucagon-like peptide-1, a new hormone of the enteroinsular axis. Diabetologia. 35:701-711.

9. Smeekens, S.P., et al. 1992. Proinsulin processing by the subtilisin-related proprotein convertases furin, PC2, and PC3. Proc. Natl. Acad. Sci. USA. 89:8822-8826.

10. Bailyes, E.M., and Hutton, J.C. 1992. Kinetic analysis of the type-1 proinsulin endopeptidase by a monoclonal antibody-based immunoadsorbent assay. Biochem. J. 286:223-229.

11. Bailyes, E.M., et al. 1992. A member of the eukaryotic subtilisin family (PC3) has the enzymic properties of the type 1 proinsulin-converting endopeptidase. Biochem. J. 285:391-394.

12. Bennett, D.L., et al. 1992. Identification of the type 2 proinsulin processing endopeptidase as PC2, a member of the eukaryote subtilisin family. J. Biol. Chem. 267:15229-15236.

13. Raskin, P., Aydin, I., and Unger, R.H. 1976. Effect of insulin on the exaggerated glucagon response to arginine stimulation in diabetes mellitus. Diabetes. 25:227-229.

14. Orskov, C., Jeppesen, J., Madsbad, S., and Holst, J.J. 1991. Proglucagon products in plasma of noninsulin-dependent diabetics and nondiabetic controls in the fasting state and after oral glucose and intravenous arginine. J. Clin. Invest. 87:415-423.

15. Ward, W.K., et al. 1987. Disproportionate elevation of immunoreactive proinsulin in type 2 (non-insulin-dependent) diabetes mellitus and in experimental insulin resistance. Diabetologia. 30:698-702.

16. Yoshioka, N., Kuzuya, T., Matsuda, A., Taniguchi, M., and Iwamoto, Y. 1988. Serum proinsulin levels at fasting and after oral glucose load in patients with type 2 (non-insulin-dependent) diabetes mellitus. Diabetologia. 31:355-360.

17. Temple, R.C., et al. 1989. Insulin deficiency in non-insulin-dependent diabetes. Lancet. 1:293-295.

18. Saad, M.F., et al. 1990. Disproportionately elevated proinsulin in Pima Indians with noninsulin-dependent diabetes mellitus. J. Clin. Endocrinol. Metab. 70:1247-1253.

19. Porte, D., Jr., and Kahn, S.E. 1989. Hyperproinsulinemia and amyloid in NIDDM. Clues to etiology of islet beta-cell dysfunction? Diabetes. 38:1333-1336.

20. Kahn, S.E., and Halban, P.A. 1997. Release of incompletely processed proinsulin is the cause of the disproportionate proinsulinemia of NIDDM. Diabetes. 46:1725-1732.

21. Furuta, M., et al. 1998. Incomplete processing of proinsulin to insulin accompanied by elevation of Des-31,32 proinsulin intermediates in islets of mice lacking active PC2. J. Biol. Chem. 273:3431-3437.

22. Furuta, M., et al. 1997. Defective prohormone processing and altered pancreatic islet morphology in mice lacking active SPC2. Proc. Natl. Acad. Sci. USA. 94:6646-6651.

23. O'Rahilly, S., et al. 1995. Brief report: impaired processing of prohormones associated with abnormalities of glucose homeostasis and adrenal function. N. Engl. J. Med. 333:1386-1390.

24. Jackson, R.S., et al. 1997. Obesity and impaired prohormone processing associated with mutations in the human prohormone convertase 1 gene. Nat. Genet. 16:303-306.

25. Like, A.A., and Rossini, A.A. 1976. Streptozotocin-induced pancreatic insulitis: new model of diabetes mellitus. Science. 193:415-417.

26. Chomczynski, P., and Sacchi, N. 1987. Single-step method of RNA isolation by acid guanidinium thiocyanate-phenol-chloroform extraction. Anal. Biochem. 162:156-159.

27. Hill, R.M., et al. 1995. Characterization of the molecular forms and membrane association of Kex $2 /$ subtilisin-like serine proteases in neuroendocrine secretory vesicles. J. Neurochem. 65:2318-2326.

28. Brubaker, P.L., and Vranic, M. 1987. Fetal rat intestinal cells in monolayer culture: a new in vitro system to study the glucagon-like immunoreactive peptides. Endocrinology. 120:1976-1985.

29. Brubaker, P.L. 1988. Control of glucagon-like immunoreactive peptide secretion from fetal rat intestinal cultures. Endocrinology. 123:220-226.

30. Brubaker, P.L., Lee, Y.C., and Drucker, D.J. 1992. Alterations in proglucagon processing and inhibition of proglucagon gene expression in transgenic mice which contain a chimeric proglucagon-SV40 T antigen gene. J. Biol. Chem. 267:20728-20733.

31. Drucker, D.J., Lee, Y.C., Asa, S.L., and Brubaker, P.L. 1992. Inhibition of pancreatic glucagon gene expression in mice bearing a subcutaneous glucagon-producing GLUTag transplantable tumor. Mol. Endocrinol. 6:2175-2184.

32. Pipeleers, D.G., Pipeleers-Marichal, M., Vanbrabandt, B., and Duys, S. 1991. Transplantation of purified islet cells in diabetic rats. II. Immunogenicity of allografted islet beta-cells. Diabetes. 40:920-930

33. Zambre, Y., et al. 1998. Effect of glucose on production and release of proinsulin conversion products by cultured human islets. J. Clin. Endocrinol. Metab. 83:1234-1238.

34. Linde, S., Welinder, B.S., and Nielsen, J.H. 1993. Analysis of proinsulin and its conversion products by reversed-phase high-performance liquid chromatography. J. Chromatogr. 614:185-204. 
35. Pipeleers, D.G., et al. 1985. Interplay of nutrients and hormones in the regulation of insulin release. Endocrinology. 117:824-833.

36. Hansen, L., Deacon, C.F., Orskov, C., and Holst, J.J. 1999. Glucagon-like peptide-1-(7-36)amide is transformed to glucagon-like peptide-1-(936)amide by dipeptidyl peptidase IV in the capillaries supplying the $L$ cells of the porcine intestine. Endocrinology. 140:5356-5363.

37. Mentlein, R., Gallwitz, B., and Schmidt, W.E. 1993. Dipeptidyl-peptidase IV hydrolyses gastric inhibitory polypeptide, glucagon-like peptide-1(736)amide, peptide histidine methionine and is responsible for their degradation in human serum. Eur. J. Biochem. 214:829-835.

38. Rouille, Y., Westermark, G., Martin, S.K., and Steiner, D.F. 1994. Proglucagon is processed to glucagon by prohormone convertase PC2 in alpha TC1-6 cells. Proc. Natl. Acad. Sci. USA. 91:3242-3246.

39. Neerman-Arbez, M., Cirulli, V., and Halban, P.A. 1994. Levels of the conversion endoproteases PC1 (PC3) and PC2 distinguish between insulin-producing pancreatic islet beta cells and non-beta cells. Biochem. J. 300:57-61.

40. Li, Q.-L., Jansen, E., and Friedman, T.C. 1999. Regulation of prohormone convertase 1 (PC1) by gp130-related cytokines. Mol. Cell. Endocrinol. 158:143-152.

41. Oyarce, A.M., Hand, T.A., Mains, R.E., and Eipper, B.A. 1996. Dopaminergic regulation of secretory granule-associated proteins in rat intermediate pituitary. J. Neurochem. 67:229-241.

42. Rouille, Y., Martin, S., and Steiner, D.F. 1995. Differential processing of proglucagon by the subtilisin-like prohormone convertases PC2 and PC3 to generate either glucagon or glucagon-like peptide. J. Biol. Chem. 270:26488-26496.

43. Rothenberg, M.E., Eilertson, C.D., Klein, K., Mackin, R.B., and Noe, B.D. 1996. Evidence for redundancy in propeptide/prohormone convertase activities in processing proglucagon: an antisense study. Mol. Endocrinol. 10:331-341.

44. Tucker, J.D., Dhanvantari, S., and Brubaker, P.L. 1996. Proglucagon processing in islet and intestinal cell lines. Regul. Pept. 62:29-35.

45. Horsch, D., Goke, R., Eissele, R., Michel, B., and Goke, B. 1997. Reciprocal cellular distribution of glucagon-like peptide-1 (GLP-1) immunoreactivity and GLP-1 receptor mRNA in pancreatic islets of rat. Pancreas. 14:290-294.

46. Xu, G., Stoffers, D.A., Habener, J.F., and Bonner-Weir, S. 1999. Exendin4 stimulates both beta-cell replication and neogenesis, resulting in increased $\beta$-cell mass and improved glucose tolerance in diabetic rats. Diabetes. 48:2270-2276.

47. Shima, K., Hirota, M., and Ohboshi, C. 1988. Effect of glucagon-like peptide-1 on insulin secretion. Regul. Pept. 22:245-252.

48. Fehmann, H.C., and Habener, J.F. 1992. Insulinotropic hormone glucagon-like peptide-I(7-37) stimulation of proinsulin gene expression and proinsulin biosynthesis in insulinoma beta TC-1 cells. Endocrinology. 130:159-166.

49. Chen, L., et al. 1989. Molecular and cellular responses of islets during perturbations of glucose homeostasis determined by in situ hybridiza- tion histochemistry. Proc. Natl. Acad. Sci. USA. 86:1367-1371.

50. Orci, L., et al. 1976. Hypertrophy and hyperplasia of somatostatin-containing D-cells in diabetes. Proc. Natl. Acad. Sci. USA. 73:1338-1342.

51. Philippe, J. 1989. Glucagon gene transcription is negatively regulated by insulin in a hamster islet cell line. J. Clin. Invest. 84:672-677.

52. Wang, Z., and Gleichmann, H. 1998. GLUT2 in pancreatic islets: crucial target molecule in diabetes induced with multiple low doses of streptozotocin in mice. Diabetes. 47:50-56.

53. Charles, M.A., Fanska, R., Schmid, F.G., Forsham, P.H., and Grodsky, G.M. 1973. Adenosine 3', 5'-monophosphate in pancreatic islets: glucoseinduced insulin release. Science. 179:569-571.

54. Sharp, G.W. 1979. The adenylate cyclase-cyclic AMP system in islets of Langerhans and its role in the control of insulin release. Diabetologia. 16:287-296

55. Hellqvist, L.N., Rhodes, C.J., and Taylor, K.W. 1984. Long-term biochemical changes in the islets of Langerhans in mice following infection with encephalomyocarditis virus. Diabetologia. 26:370-374.

56. Ftouhi, N., Day, R., Mbikay, M., Chretien, M., and Seidah, N.G. 1994. Gene organization of the mouse pro-hormone and pro-protein convertase PC1. DNA Cell Biol. 13:395-407.

57. Hanabusa, T., Ohagi, S., LaMendola, J., Chan, S.J., and Steiner, D.F. 1994. Nucleotide sequence and analysis of the mouse SPC3 promoter region. FEBS Lett. 356:339-41.

58. Jansen, E., Ayoubi, T.A., Meulemans, S.M., and Van de Ven, W.J. 1995. Neuroendocrine-specific expression of the human prohormone convertase 1 gene. Hormonal regulation of transcription through distinct cAMP response elements. J. Biol. Chem. 270:15391-15397.

59. Jansen, E., Ayoubi, T.A., Meulemans, S.M., and Van de Ven, W.J. 1997. Regulation of human prohormone convertase 2 promoter activity by the transcription factor EGR-1. Biochem. J. 328:69-74.

60. Alarcon, C., Lincoln, B., and Rhodes, C.J. 1993. The biosynthesis of the subtilisin-related proprotein convertase PC3, but no that of the PC2 convertase, is regulated by glucose in parallel to proinsulin biosynthesis in rat pancreatic islets. J. Biol. Chem. 268:4276-4280.

61. Martin, S.K., Carroll, R., Benig, M., and Steiner, D.F. 1994. Regulation by glucose of the biosynthesis of PC2, PC3 and proinsulin in (ob/ob) mouse islets of Langerhans. FEBS Lett. 356:279-282.

62. Schuppin, G.T., and Rhodes, C.J. 1996. Specific co-ordinated regulation of PC3 and PC2 gene expression with that of preproinsulin in insulinproducing beta TC3 cells. Biochem. J. 313:259-268.

63. Skelly, R.H., Schuppin, G.T., Ishihara, H., Oka, Y., and Rhodes, C.J. 1996. Glucose-regulated translational control of proinsulin biosynthesis with that of the proinsulin endopeptidases PC2 and PC 3 in the insulin-producing MIN6 cell line. Diabetes. 45:37-43.

64. Alarcon, C., Leahy, J.L., Schuppin, G.T., and Rhodes, C.J. 1995. Increased secretory demand rather than a defect in the proinsulin conversion mechanism causes hyperproinsulinemia in a glucose-infusion rat model of non-insulin-dependent diabetes mellitus. J. Clin. Invest. 95:1032-1039. 